\title{
MENSAGEM À TURMA IEDA BARREIRA E CASTRO
}

\author{
* Ieda B. e Castro
}

\begin{tabular}{|l|l|} 
\\
\hline
\end{tabular}

CASTRO, I.B. - Mensagem à turma Ieda Barreira e Castro. Rev. Bras. Enf.; DF, 32 : 7, 1979.

Embora impossibilitada de comparecer à solenidade de formatura da Turma de 1978, que me honrou ao escolher meu nome para sua própria denominação, não quero deixar de consignar nesta hora o orgulho que sinto por receber tão significativa homenagem das enfermeiras pernambucanas.

A admiração e o reconhecimento dos jovens sempre é gratificante, principalmente quando as incompreensões entre as gerações são tão freqüentes e às ve.. zes graves.

Um outro aspecto aumenta para mim a importância do gesto de vocês.

As primeiras vivências profissionais, tão marcantes e decisivas, as tive no Recife, como integrante da então Campanha Nacional Contra a Turberculose. Também no Recife comecei a atuar com mais empenho na Associação, ao participar da organização do XX Congresso Brasileiro de Enfermagem, em 1968. Na Semana da Enfermagem do ano seguin.. te recebi da Associação Brasileira de Enfermagem, Seção Pernambuco, uma homenagem que foi entendida como um agradecimento pela contribuição prestada ao sucesso daquele evento.

$\mathrm{Na}$ época afirmei "as primeiras experiências são sempre as mais emocionantes e esta é a primeira homenagem que recebo de minha associação de classe". Agora reafirmo o que disse há quase dez anos, pois esta à a primeira homenagem que recebo de estudantes que não são os da escola de enfermagem onde ensino.

Compreendo também que o meu nome foi escolhido por representar a Associação Brasileira de Enfermagem, com toda sua tradição de relevantes serviços prestados à sociedade brasileira.

Nesta oportunidade, quero, em meu próprio nome e em nome da ABEn, conclamá-los a que assumam uma posição consciente quanto aos destinos da profissão em que ora ingressam, pois a enfermagem será neste País o que dela fizerem os enfermeiros. E o futuro pertence a vocês.

\footnotetext{
* Mensagem enviada à turma de enfermeiras formadas no ano de 1978 pela Universidade Federal de Pernambuco. A referida turma homenageou a Presidente da ABEn, tomando o seu nome.
} 